\title{
Out Beyond the Ideas of Wrongdoing and Rightdoing...
}

\author{
HEESOON BAI \\ Simon Fraser University (Canada)
}

I have been asked to write a small de-light-fully playful piece on ethics in the key of complexity theory ${ }^{1}$. First, I must frame my dim-sum ${ }^{2}$ offering with some explanations. I shall start with a rather simple-to-describe, even if difficult-to-practice, understanding that the task of ethics is to guide us to live peacefully and beautifully with and for each other on this precious blue planet teaming with life. What else are ethics good for? Since ethics are meant to guide our dealings with living breathing beings in a living breathing environment that is always changing, including our understanding of what the world that we are living in is like, ethics has to be re-discovered and re-fashioned for every society, generation, and participating individual. Ethics must demonstrate its efficacy of resonance with the world around. Thus the first task of ethics is ontological: What is our picture of the world and ourselves situated within it today?

Welcome to the Age of Complexity and to the Participatory Universe (Skolimouwski, 1995). Our picture of what the world and life are like have changed from the days of Descartes and Newton when they pictured it to be a Mechanical Universe (see Bai, 2001) and saw our world, including human beings, as bounded, discrete, and linear systems. Today, in this Age of Complexity and Participation, we have the opportunity to see our world as nonlinear (complex), implicate or interdependent, hence

\footnotetext{
${ }^{1}$ I explored this topic in a more extended way with co-author Hartley Banack (Bai and Banack, 2006).

2 The literal meaning of dim-sum (點心) is ‘touch the heart'. Perhaps a more poetic translation would be a touch of heart. Dim sum is usually a lunch fare with a wide variety of small dishes that delight the heart. May this small writing touch the Reader's heart!
} 
relational and participatory. How does this ontological view translate into ethical understanding and conduct? What does living in the way that complexity theory suggests look like?

Intriguingly enough, an ethics founded upon the understanding of complexity theory is what the Zen folks have been talking about for millennia in terms of enlightenment. This should not be too surprising. Zen ${ }^{3}$ and Complexity share a worldview that sees the comings and goings of the world, including human affairs, to be, to repeat, non-linear (complex), implicate and so on. Hence, I am thinking that one way of exploring the question that I posed above - what it is like to live ethically in the framework of complexity theory - is to look at how the Zen folks go about enacting their understanding of nonlinearity and participation. It turns out that they have a long and deep tradition of learning to embody and enact that ontological view: this is known as enlightenment ('bodhi' meaning 'awakening'). Enlightenment for the Zen folks is nothing other than an abiding and embodied realization of the nonlinear worldview (rather than an intellectual comprehension, such as the scientific understanding of the complexity theory). This is why enlightenment has a profound impact on how we perceive, think, feel, and act - that is, on ethics.

Now, ethics and education are intimately linked. In fact, I would say that education is about and for ethics: education is learning the ways of life that promote well-being for all sentient beings with whom we share our planet. Ultimately, what else is education for? If that is not the "bottom line" for any conception of education, such education is miseducation. In identifying enlightenment with the ways of being under the auspices of complexity theory, I suggest that we see enlightenment as our curriculum. We need to teach our young and young-at-heart the ways of enlightenment: embodied, experiential realization of nonlinearity, relationality, and participation. Imagine what a classroom would be like if teachers and students see the classroom learning and teaching as an enlightenment opportunity and practice! In what follows, instead of explaining what complexity theory is, and what Zen is, and how education fits into all this, I will use Zen stories to evoke complexity theory and its ethical and pedagogical implications.

Sosan says:

Rather than focus on knowing the truth simply cease to be seduced by your opinions.

If there is even an inkling of right or wrong the enlightened mind ceases to be. 4

\footnotetext{
3 'Zen' (in Chinese, 'chan', in Korean, 'son') means 'meditative state of consciousness'. This word comes from the Sanskrit word 'dhyana' that refers to a non-ordinary state of consciousness. Ordinary states of consciousness (OSC) see the world in linear causation, atomism, and subject-object duality. Enlightenment is an experience of OSC falling away and seeing oneself and the world interdependent, co-arising, and thereby continually creating patterns that interconnect.

${ }^{4}$ See The Book Laboratory's The Book of Nothing: A song of enlightenment. (p. 35). This work was written in the sixth century by Sosan.
} 
Sosan is long-dead, but that does not stop this Zen Master from teaching me today. Dharma (teachings) is timeless and placeless. It takes place anywhere and anytime, if only we could hear it. ${ }^{5}$ So, in reverie and reverence, I reply to Sosan:

Master Sosan, what are you talking about? So, an enlightened person cannot tell what is wrong from what is right? Or she can tell but she does not let that guide her action? Zen Master Sosan, explain all this to me. I may be an unenlightened academic but I am open to learning.

At this point, Nan-in, another of my virtual Zen masters, ${ }^{6}$ pops into our conversation and speaks:

One day I had a visitor, a university professor who wanted to know about Zen. As is customary, I served tea. I started to pour my visitor's cup, and I filled it, and I kept on pouring. The professor went into shock momentarily, and then he blurted out.

"It is overfull. No more will go in!"

"Indeed," said I, "you said it well.7

I face both Sosan and Nan-in, and address them together:

This is all very confusing. I get this vague sense that there is some connection between an enlightened person's avoidance - I see a flicker of some emotion on their face when my Zen masters heard 'avoidance' - of thinking in terms of "right or wrong" and the lesson that the professor is learning, namely that the cup needs to be empty. Please, you must know what I don't! Please explain everything plainly and clearly. All this makes no logical sense to me. Please de-confuse me. As I spoke, I felt a heat of both frustration and hope rising in me. I was about to get down on my knee and implore somebody, but who?

My virtual Zen masters look at each other silently for a moment, and turn to me. Nan-in speaks:

The Zen master Hakuin was praised by his neighbors as one living a pure life. A beautiful Japanese girl whose parents owned a food store lived near him. Suddenly, without any warning, her parents discovered she was with child. This made her parents angry. She would not confess who the man was, but after much harassment at last named Hakuin. In great anger the parents went to the master. "Is that so" was all he would say in response to their angry accusations. After the child was born it was brought to Hakuin. By this time he had lost his reputation, which did not trouble him. He took very good care of the child. He obtained milk from his neighbors and everything else the little one needed. A year later the girl-mother could stand it no longer. She told her parents the truth-that the real father of the child was a young man who worked in the fishmarket. The mother and father of the girl at once went to Hakuin to ask his forgiveness, to

\footnotetext{
${ }^{5}$ This notion that teaching (dharma) happens all the time and everywhere simultaneously if only we are willing to hear and see is classic in Buddhism.

${ }^{6}$ Nan-in was a Zen master during the Meiji era: 1868-1912.

${ }^{7}$ Based on the writings of Nan-in. See “A cup of tea” in Reps and Senzaki (1985), p. 19.
} 
apologize at length, and to get the child back again. Hakuin was willing. In response to their apology and while yielding the child, all he said was: "Is that so?"8

Yet another story! At this point, I lose my calm and cool altogether. My frustration level with these devious Zen masters has reached its all time high - I do tend to lose my cool easily - and I am about to walk out. Surely I need, and deserve, a different kind of discourse community: one more reason-able than what these two inscrutable Zen masters are offering! Why can't they be straight and get to the point? Just explain clearly and step by step instead of running me around with stories that seem to evoke and provoke something or another but explain nothing. I felt like a grey fog was swallowing up my brain. I could feel this irritation rising up in me. What was the point of Hakuin's story? I am now nearly shouting at the Zen masters.

Why did Hakuin not say to the girl's parents from the beginning: "I am not the father of this baby. You are wrong!" What is wrong with telling the truth?"

Another spell of silence, this time longer than the last. Again they look at each other. This time Sosan speaks:

Please notice the aggressive energy in your voice. How is the state of your heart? Full of tension, frustration, anger? Do you feel profound compassion in you? Do you feel boundless generosity and care in you this moment? Did I not say, "If there is even an inkling of right or wrong the enlightened mind ceases to be"? Again you want to talk about "right" and "wrong"! The talk of right and wrong belongs to conventional ethics that becomes necessary after we have lost the sight of our Buddha Nature - this profoundly compassionate, radiant, and generous mind-heart that cannot be shut into the linear box of reason and logic. Enlightenment is nothing other than rediscovering our Buddha Nature. Trying to sort out or learn what is right and what is wrong will not take us to enlightenment. That very consciousness of thinking right and wrong - that "left-brain" activity that preoccupies us so much - will block you from getting in touch with your genuine Buddha Nature. The more time and energy you spend in thinking right and wrong, the further away you will be from the cultivation of profound compassion and generosity that simply emerge from the perception that "me" and the world are one. While it is helpful to know how right and wrong operate in the world, as we are invariably part of this world, if you wish to become deeply compassionate, generous, and caring towards the world, including yourself, then what you need to do is to touch and taste the Buddha Nature (we really don't care what you call it) in your self and in others. You need to get out of your linearity more often, and make your home in nonlinearity. ${ }^{9}$

With these words, Sosan and Nan-in vanish, and I am suddenly snapped out of my linear consciousness that was always separating and sorting, labeling and judging. It is as though I am suddenly transported into a wide, open field of luminosity, pulsating with fullness and oneness of life. I am at once struck by the ineffability of such

\footnotetext{
${ }^{8}$ See Reps and Senzaki (1985), p. 22. Hakuin lived from 1686 to 1768.

${ }^{9}$ This paragraph is not based on any actual text written by Sosan.
} 
experience. Closest to articulating what such experience is like would be through these lines from Rumi:

Out beyond ideas of wrongdoing and rightdoing,

there is a field. I'll meet you there.

When the soul lies down in that grass,

the world is too full to talk about.

Ideas, language, even the phrase "each other"

doesn't make any sense. ${ }^{10}$

Complexity theory describes our phenomenal world to be nonlinear, mutual, and participatory. The consciousness that can experience the world this way cannot be too serious about categorically and unambiguously separating wrongdoing from rightdoing, good from bad, sacred from profane, true from false, body/matter from mind, self from other, and this from that. The consciousness of complexity, like the Zen consciousness, sees mutual implicatedness of everything in everything else. Realizing our interbeingness, one naturally practices humility, compassion, care and generosity. Dear Readers, may this discursive dim-sum offering touch and arouse Bodhicitta (mind of enlightenment) in you!

\title{
References
}

Bai, H. (2001) Challenge for education: Learning to value the world intrinsically. Encounter, 14 (1) 4-16.

Bai, H \& Banack, H. (2006). 'To see a world in a grain of sand': Complexity and moral education, Complicity: An International Journal of Complexity and Education, 3 (1) 5-20.

Barks, C. (1997). The essential Rumi Edison, NJ: Castle Books.

Skolimouwski, H. (1995). The participatory mind: A new theory of knowledge and of the universe. London: Penguin.

The Book Laboratory, Inc. (2002). The book of nothing: A song of enlightenment. Kansas City: Andrews McMeel Publishing.

Reps, P \& Senzaki, N. (1985). Zen flesh Zen bones: A collection of Zen and pre-Zen writings. Boston: Turtle Publishing.

\begin{abstract}
About the Author
Heesoon Bai is an Associate Professor at Simon Fraser University in the Faculty of Education. She is currently the Director of Graduate Programs in the Faculty of Education, Coordinator for the Philosophy of Education PhD program, and Editor of Paideusis, the International Journal of the Canadian Philosophy of Education Society. She is the recipient of the 2008 Canadian Society for the Study of Education (Graduate Student Chapter) Mentorship Award, and in 2003, she received the Simon Fraser University Excellence in Teaching Award. Dr. Bai's research interests are wide-ranging
\end{abstract}

${ }^{10}$ See Barks’ (1997) translation of Rumi, p.36. 
and include, Zen aesthetics, ecology, ethics of care, complexity theory, and the making of exceptional educators. Her recent publications focus on contributions to education and counseling by the application of Asian philosophies, e.g., mindfulness.

(C) Copyright 2008. The author, HEESOON BAI, assigns to the University of Alberta and other educational and non-profit institutions a non-exclusive license to use this document for personal use and in courses of instruction provided that the article is used in full and this copyright statement is reproduced. The author also grants a non-exclusive license to the University of Alberta to publish this document in full on the World Wide Web, and for the document to be published on mirrors on the World Wide Web. Any other usage is prohibited without the express permission of the authors. 